\title{
HUBUNGAN TINGKAT PENGETAHUAN IBU HAMIL TENTANG EMESIS GRAVIDARUM DENGAN PERUBAHAN BERAT BADAN TRIMESTER 1 DI PUSKESMAS BATURITI 1 TAHUN 2017
}

\author{
Hesteria Friska Armynia Subratha, Dewa Ayu Ari Kusumayuni \\ Program Studi Diploma III Kebidanan, STIKES Advaita Medika Tabanan \\ Email : hesteria.friska@yahoo.com
}

\begin{abstract}
ABSTRAK
Latar Belakang Emesis gravidarum adalah gejala yang wajar atau sering terjadi pada kehamilan trimester I, hal inilah yang menyebabkan rasa tidak nyaman pada ibu hamil, namun kurangnya pengetahuan ibu tentang emesis gravidarum juga dapat memperparah kondisi ibu hingga terjadinya penurunan berat badan yang drastis. Tujuan Penelitian ini adalah untuk mengetahui hubungan tingkat pengetahuan ibu hamil tentang emesis gravidarum dengan perubahan berat badan ibu hamil trimester $1 \mathrm{di}$ Puskesmas Baturiti tahun 2017.nMetode penelitian ini adalah dengan menggunakan pendekatan cross sectional. Variabel yang digunakan adalah variabel independent yaitu tingkat pengetahuan tentang emesis gravidarum dan variabel dependentnya adalah perubahan berat badan ibu hamil trimester 1 yang mengalami emesis gravidarum.Sampel penelitian sebanyak 34 orang diambil dengan teknik total sampling. Data dikumpulkan dengan menyebarkan test dan lembar observasi berat badan. Teknik analisis yang digunakan untuk menganalisa adalah uji korelasi Spearman Rank. Hasil penelitian menunjukan tingkat pengetahuan responden paling banyak dalam kategori kurang yaitu 16 orang $(47,05 \%)$ dan perubahan berat badan yang paling banyak dalam kategori turun yaitu 19 orang $(55,88 \%)$. Berdasarkan hasil uji korelasi pada analisis data diperoleh nilai $P=0,00$ lebih kecil dari $\alpha 0,05$ dan $r_{\text {ho }}$ sebesar 0,654 . Temuan ini menunjukkan bahwa ada hubungan positif dan kuat antara tingkat pengetahuan ibu hamil tentang emesis gravidarum dengan perubahan berat badan ibu hamil trimester 1. Simpulan yang dapat diambil dari penelitian ini adalah berdasarkan hasil penelitian tersebut hendaknya petugas kesehatan di puskesmas lebih efektif dalam memberikan informasi tentang emesis gravidarum agar tidak terjadi penurunan berat badan yang sangat drastis.
\end{abstract}

Kata kunci : Pengetahuan, Perubahan Berat Badan, Ibu Hamil Emesis Gravidarum 


\section{PENDAHULUAN}

Emesis gravidarum adalah gejala yang wajar dan sering didapatkan pada ibu hamil trimester I. Mual dan muntah biasanya terjadi pada pagi hari tetapi dapat pula timbul setiap saat pada malan hari. Emesis gravidarum kurang lebih terjadi 6 minggu setelah hari pertama haid terakhir. Pada umumnya wanita dapat menyesuaikan dengan keadaan ini, meskipun gejala mual dan muntah yang berat dapat berlangsung sampai 4 bulan. Pekerjaan sehari-hari menjadi terganggu dan keadaan umum menjadi buruk yang disebut hiperemesis gravidarum (Prawirohardjo, 2005).

Keluhan yang sering terjadi pada hampir 50-90\% wanita hamil pada trimester satu adalah mual (nausea) dan muntah (emesis gravidarum). Emesis gravidarum adalah muntah-muntah pada wanita hamil (Dorlan, 2002). Keadaan ini biasanya didahului rasa mual (nausea). Mual muntah biasanya terjadi pada pagi hari tetapi dapat pula timbul pada saat malam hari. Perubahan bentuk tubuh yang terjadi pada ibu dengan emesis yaitu berat badan cenderung turun atau ibu terlihat lebih kurus, turgor kulit berkurang dan mata terlihat cekung. Dewasa ini masih tingginya kejadian emesis gravidarum yang dikeluhkan oleh ibu-ibu hamil trimester 1, gejala tersebut kebanyakan terjadi pada primigravida dan beberapa pada multigravida.

Data dari Profil Kesehatan Kabupaten/Kota di Bali Tahun 2015 dan Badan Statistik Provinsi Bali, diproleh data angka kesakitan ibu hamil di Provinsi Bali 15.822 orang, sementara di wilayah Kabupaten Tabanan jumlahnya 189 orang. Jumlah kunjungan ibu hamil ( K1 ) Tahun 2016 untuk Provinsi Bali 64.656 orang, untuk wilayah Kabupaten Tabanan 5.323 orang dan K1 Puskesmas baturiti I 457 orang $(103 \%)$.

Menurut (Manuaba,2006) beberapa ibu hamil yang mengalami mual muntah yang berlebihan ( Hiperemesis Gravidarum) akan kehilangan berat badan $>5 \%$ dari berat badan sebelum hamil, sehingga penurunan berat badan untuk kategori emesis gravidarum peneliti mengambil maksimal mencapai $5 \%$ dari berat badan sebelum hamil, maka dapat disimpulkan bahwa untuk kategori turun jika ibu hamil trimester 1 yang mengalami emesis gravidarum mengalami penurunan berat badan maksimal mencapai 5\%, kategori tetap jika ibu hamil trimester 1 yang mengalami mual muntah tidak mengalami perubahan berat badan dari berat badan sebelum hamil, dan untuk kategori naik jika ibu hamil trimester 1 yang mengalami emesis gravidarum mengalami kenaikan berat badan dari berat badan sebelum hamil.

Salah satu upaya yang dilakukan pemerintah adalah dengan mencanangkan program kunjungan ANC minimal 4 kali selama kehamilan, dimana salah satunya adalah kunjungan $\mathrm{K} 1$ yang bertujuan untuk mendeteksi komplikasi-komplikasi kehamilan lebih dini, sehingga keluhan dan komplikasi yang di alami ibu hamil dapat segera diatasi. Selain itu untuk mengurangi gejala-gejala terjadinya mual dan muntah yaitu dengan memberikan pendidikan kesehatan atau penyuluhan kepada ibu hamil.

Hasil dari prasurvey pendahuluan yang penulis lakukan di Poli KIA Puskesmas Baturiti 1 dari 20 orang ibu hamil trimester 1 diperoleh data bahwa terdapat $14 \mathrm{ibu}$ hamil yang mengalami emesis gravidarum dan perubahan berat badan yaitu turun, tetap, ada yang naik, setelah dilakukan pemeriksaan terdapat 11 ibu hamil yang mengalami penurunan berat badan.

\section{METODE PENELITIAN}

Jenis penelitian ini adalah asosiatif dengan pendekatan cross sectional. Populasi penelitian adalah keseluruhan subjek penelitian atau subjek yang diteliti (Notoatmodjo, 2005). Populasi yang digunakan dalam penelitian ini adalah semua ibu hamil trimester 1 yang mengalami keluhan mual muntah atau emesis gravidarum saat berkunjung di Puskesmas Baturiti 1 bulan Juni - Juli 2017. 
Menurut Hidayat (2007), sampel merupakan bagian populasi yang akan diteliti atau sebagian jumlah dari karakteristik yang dimiliki oleh populasi. Pada penelitian ini sampelnya adalah semua ibu hamil trimester 1 dengan keluhan mual muntah atau emesis gravidarum yang melakukan kunjungan ke Puskesmas Baturiti 1 pada bulan Juni - Juli 2017 yaitu sebanyak 34 orang.

Berdasarkan populasi yang akan diambil untuk bisa dijadikan sampel harus memenuhi kreteria inklusi dan eksklusi

1. Kreteria inklusi dalam penelitian ini adalah :
a. Ibu hamil yang ada di wilayah kerja Puskesmas Baturiti I
b. Ibu hamil yang umur kehamilannya dibawah 12 minggu
c. Ibu hamil yang mengalami emesis gravidarum
d. Ibu hamil yang kooperatif dan bersedia menjadi responden

2. Kreteria eksklusi dalam penelitian ini adalah:

a. Ibu hamil yang tidak mengalami emesis gravidarum

b. Ibu hamil yang usia kehamilannya diatas 12 minggu dan mengalami emesis gravidarum

c. Ibu hamil yang menderita gastritis kronis

Pada penelitian ini pengambilan besar sampel ditentukan dengan cara total sampling.

Dalam penelitian ini yang menjadi sampel yaitu semua ibu hamil yang mengalami keluhan mual muntah yang berkunjung ke Puskesmas Baturiti I pada bulan Juni-Juli 2017.

Penelitian dilaksanakan di Wilayah

Kerja Puskesmas Baturiti I Kecamatan Baturiti Kabupaten Tabanan. Waktu penelitian dilaksanakan pada bulan Juni Juli 2017.

Untuk mengumpulkan data, peneliti menggunakan sumber data primer pada bulan Mei 2017. Pada penelitian ini cara pengumpulan data yang digunakan adalah lembar Koesioner, lembar observasi dan buku kunjungan KIA ibu.
Penelitian ini merupakan jenis penelitian asosiatif, maka setelah data dikumpulkan dan data diperiksa, kemudian dilakukan analisa data dengan menggunakan uji statistik non parametrik yaitu Korelasi Spearman Rank. Korelasi Spearman Rank digunakan untuk mencari hubungan dan membuktikan hipotesis hubungan dua variabel yang dinyatakan dengan skala ordinal dan sumber data dari dua variabel tidak sama dan variabel tidak harus membentuk distribusi normal.

Prosedur perhitungan Korelasi Spearman Rank adalah sebagai berikut :

$R h o=1-\frac{6 \sum B^{2}}{n\left(n^{2}-1\right)}$

Keterangan :

$r_{h o}=$ koefisien korelasi Rank Spearman

$\mathrm{B}=$ beda, yaitu selisih nilai variabel 1 dengan variabel 2

$\mathrm{n}$ = banyaknya subjek pemilik nilai

Analisis data penelitian dilakukan pada tingkat kepercayaan $95 \%$ dengan pogram Statistical Product and Service Solution (SPSS) . H0 ditolak bila $\mathrm{p}<0,05$, berarti ada hubungan tingkat pengetahuan ibu hamil tentang emesis gravidarum dengan perubahan berat badan ibu hamil trimester I. H0 diterima bila $\mathrm{p}>0,05$, berarti tidak ada hubungan antara tingkat pengetahuan ibu hamil tentang emesis gravidarum dengan perubahan berat badan ibu hamil trimester I

\section{HASIL}

Penelitian ini dilakukan di Puskemas Baturiti 1. Lokasi UPTD Puskesmas Baturiti I berada di Jalan raya Denpasar - Singaraja, Desa Baturiti, Kecamatan Baturiti, Kabupaten Tabanan, Provinsi Bali. Wilayah kerja UPTD Puskesmas Baturiti I mewilayahi tujuh desa dari dua belas desa yang ada di Kecamatan Baturiti. Adapun tujuh desa tersebut yaitu: Desa Baturiti, Desa Bangli, Desa Batunya, Desa Antapan, Desa Candikuning, Desa Apuan dan Desa Angsri.

Adapun karakteristik responden penelitian yang telah diteliti dan disajikan dalam tabel adalah karakteristik responden 
berdasarkan umur, pendidikan terakhir, pekerjaan dan usia kehamilan ibu saat ini.

1. Karakteristik Responden Berdasarkan Umur

Distribusi responden berdasarkan umur menunjukkan bahwa dari 34 responden paling banyak berumur antara 20-35 tahun yaitu sebanyak 23 orang $(67,64 \%)$, umur < 20 tahun sebanyak 8 orang $(23,52 \%)$, umur > 35 tahun sebanyak 3 orang $(8,82 \%)$.

2. Karakteristik Responden Berdasarkan Pendidikan

Distribusi responden berdasarkan pendidikan menunjukkan bahwa sebagian besar responden yang mengalami emesis gravidarum memiliki pendidikan terakhir SMP yaitu sebanyak 16 orang $(47,05 \%)$, SMA 9 orang $(26,47 \%)$, Akademi 5 orang $(14,70 \%)$, dan SD 4 orang $(11,76 \%)$.

3. Karakteristik Responden Berdasarkan Pekerjaan

Distribusi responden berdasarkan pekerjaan tampak bahwa sebagian besar responden adalah buruh/petani yaitu sebanyak 16 orang ( $47,05 \%$ ), ibu rumah tangga (IRT) sebanyak 12 orang $(35,29 \%)$, karyawan swasta sebanyak 5 orang ( $14,70 \%)$, PNS/POLRI/ABRI sebanyak 1 orang $(2,94 \%)$

4. Karakteristik Responden Berdasarkan Umur Kehamilan

Distribusi responden berdasarkan usia kehamilan menunjukkan bahwa dari 34 responden sebagian besar usia kehamilan responden adalah 2 bulan yaitu sebanyak 16 orang $(47,05 \%)$, usia kehamilan 3 bulan 14 orang $(41,17 \%)$, usia kehamilan 1 bulan 4 orang $(11,76 \%)$

5. Karakteristik Responden Berdasarkan Tingkat pengetahuan Ibu Tentang
Emesis Gravidarum pada Ibu Hamil Trimester 1

Karakteristik responden berdasarkan tingkat pengetahuan ibu tentang Emesis Gravidarum pada ibu hamil trimester 1 menunjukkan dari 34 responden terdapat 16 orang $(47,05 \%)$ yang memiliki pengetahuan kurang, 10 orang $(29,41 \%)$ responden memiliki pengetahuan cukup dan 8 orang $(23,52 \%)$ responden memiliki pengetahuan baik.

6. Karakteristik Responden Berdasarkan Perubahan Berat Badan Ibu Hamil Trimester 1 yang mengalami Emesis Gravidarum.

Karakteristik responden berdasarkan perubahan berat badan ibu hamil trimester 1 yang mengalami Emesis Gravidarum. Menunjukkan dari 34 responden paling banyak mengalami penurunan berat badan yaitu sebanyak 19 orang $(55,88 \%), 9$ orang $(26,47 \%)$ responden dengan katagori berat badan tetap, 6 orang $(17,64 \%)$ responden dengan katagori berat badan naik.

7. Distribusi Responden Berdasarkan Hubungan Tingkat Pengetahuan Ibu Hamil Tentang Emesis Gravidarum Dengan Perubahan Berat Badan Ibu Hamil Trimester 1 di Puskesmas Baturiti I.

Sebanyak 4 responden $(11,76 \%)$ memiliki tingkat pengetahuan yang baik tentang emesis gravidarum mengalami kenaikan berat badan, 4 responden $(11,76 \%)$ memiliki tingkat pengetahuan baik dengan berat badan tetap. 1 responden $(2,94 \%)$ memiliki tingkat pengetahuan cukup dan berat badannya naik, 5 responden $(14,70 \%)$ memiliki tingkat pengetahuan cukup dengan berat badan tetap dan 4 responden $(11,76 \%)$ dengan berat badan turun. Tingkat pengetahuan kurang yaitu 1 responden $(2,94 \%)$ mengalami kenaikan berat badan dan 15 responden $(44,11 \%)$ mengalami penurunan berat badan. 
\begin{tabular}{lccr}
\multicolumn{2}{c}{ Korelasi } & antara & variabel \\
pengetahuan & dan & variabel & sikap \\
menggunakan & uji & korelasi & Rank \\
Spearman & diolah & dengan & pogram
\end{tabular} Statistical Product and Service Solution (SPSS). Kemaknaan korelasi dilihat dari nilai $\mathrm{p}$,dimana Uji korelasi bermakna bila $\mathrm{p}<0,05$. Hasil analisa data menunjukkan bahwa nilai $\mathrm{P}$ yang dilihat dari sig (2-tailed ) adalah sebesar 0.00. Nilai ini lebih kecil dari $\alpha$ yang disyaratkan sebesar $0,05 \quad(5 \%)$. Ini berarti hipotesis menyatakan bahwa ada hubungan antara variabel pengetahuan tentang emesis gravidarum dengan perubahan berat badan ibu hamil trimester I.

Nilai koefisien korelasi ( rho ) antara variabel pengetahuan dan perubahan berat badan seperti yang ditunjukkan pada lampiran adalah sebesar 0,654. Nilai tersebut bertanda positif yang berarti terdapat hubungan positif antara tingkat pengetahuan tentang emesis gravidarum dengan perubahan berat badan ibu hamil trimester I. Nilai koefisien korelasi ( rho ) sebesar 0,654 berada pada kisaran $0,60-0,799$ sesuai dengan interpretasi tingkat hubungan pada tabel 3.2 dapat diinterpretasikan bahwa ada hubungan yang kuat antara tingkat pengetahuan tentang emesis gravidarum dengan perubahan berat badan ibu hamil trimester I.

\section{PEMBAHASAN}

1. Tingkat Pengetahuan Tentang Emesis Gravidarum Pada Ibu Hamil Trimester 1 Karakteristik responden berdasarkan tingkat pengetahuan ibu hamil tentang emesis gravidarum, paling banyak responden mempunyai tingkat pengetahuan yang kurang yaitu sebanyak 16 orang $(47,05 \%)$. Hal ini dapat disebabkan oleh faktor pendidikan responden. Hal tersebut ditegaskan oleh Notoatmodjo (2005), bahwa tingkat pendidikan seseorang dapat mempengaruhi pengetahuannya, dimana semakin tinggi tingkat pendidikan sesorang maka informasi yang didapat bisa diserap dengan baik sehingga tingkat pengetahuannya akan semakin tinggi. Tidak dapat dipungkiri bahwa makin tinggi pendidikan seseorang maka semakin mudah pula mereka menerima informasi dan pada akhirnya makin banyak pula pengetahuan yang dimilikinya. Kuncoroningrat (dalam Nursalam dan Pariani, 2001) menyatakan bahwa semakin tinggi tingkat pendidikan seseorang maka makin mudah dalam menerima informasi sehingga makin banyak pula pengetahuan yang dimiliki. Dalam penelitian ini responden paling banyak berpendidikan SMP yaitu sebanyak 16 orang $(47,05 \%)$.

Pengalaman juga mempengaruhi pengetahuan seseorang, sesuatu yang pernah dialami seseorang akan menambah pengetahuan orang tersebut dan dapat menjadi sumber pengetahuan yang bersifat informal, seperti pada data umum yang didapat oleh peneliti ditempat penelitian paling banyak keluhan mual muntah ditemui pada usia kehamilan 2 bulan yaitu sebanyak 16 orang $(47,05 \%)$. Pada awal kehamilan belum banyak pengalaman ibu hamil dalam mengatasi keluhan mual dan muntah. Hal inilah yang mempengaruhi pengetahuan responden, secara otomatis keluhan akan bisa diatasi sesuai pengalaman yang pernah dia alami. Karena hal inilah pengalaman seseorang sangat mempengaruhi pengetahuan hingga akhirnya membentuk sikap positif dalam kehidupannya.

Pengetahuan juga dipengaruhi oleh umur, dalam penelitian ini beberapa responden berumur kurang dari 20 tahun yaitu sebanyak 8 orang $(23,52 \%)$, umur dapat mempengaruhi pengetahuan seseorang, semakin tua umur seseorang maka kemampuan dan kematangan seseorang akan lebih tinggi baik dari cara berfikir maupun dalam bertindak. 
Berdasarkan hasil penelitian di Puskesmas Baturiti 1 menunjukan bahwa dari 34 responden yang mengalami perubahan berat badan diantaranya terdapat 6 orang $(17,64 \%)$ yang mengalami kenaikan berat badan, 9 orang $(26,47 \%)$ yang tidak mengalami perubahan berat badan dan yang paling banyak yaitu responden yang mengalami penurunan berat badan sebanyak 19 orang $(55,88 \%)$. Dalam hal ini dapat kita amati pada tabel 4.2 mengenai karakteristik responden berdasarkan perubahan berat badan ibu hamil trimester 1 yang mengalami emesis gravidarum. Hal tersebut dapat terjadi karena pengetahuan ibu hamil yang kurang tentang emesis gravidarum - Sedangkan dalam penelitian ini mayoritas responden berpendidikan terakhir SMP sehingga informasi yang diberikan hanya sedikit yang bisa dipahami maka dapat mempengaruhi perubahan berat badan ibu.

2. Perubahan Berat Badan Ibu Hamil Trimester 1 yang mengalami emesis gravidarum

Ibu hamil yang mengalami penurunan berat badan dipengaruhi oleh beberapa faktor yaitu faktor pola makan, ibu yang mengalami emesis pada saat hamil akan mengalami perubahan pola makan. Hal ini disebabkan karena nafsu makan ibu yang menurun akibat perasaan mual yang dialaminya sehingga asupan nutrisi ibu hamil berkurang sehingga menyebabkan penurunan berat badan pada ibu hamil.

Selain faktor pola makan, faktor aktivitas juga mempengaruhi perubahan berat badan. Ibu hamil yang memiliki aktivitas berlebih sangat mempengaruhi perubahan berat badan, dalam hal ini mayoritas responden memiliki pekerjaan sebagai petani/buruh yang mempunyai aktivitas cukup berat. Hal ini sesuai dengan teori Maydav (2011) mengatakan bahwa aktivitas yang berlebih bisa menyebabkan berat badan akan cepat sekali turun dan tentunya sulit dikembalikan. Berdasarkan hasil penelitian di Puskesmas Baturiti 1 menunjukan bahwa dari 34 responden yang mengalami perubahan berat badan, sebanyak 16 orang $(47,05 \%)$ responden bekerja sebagai petani/buruh/pedagang. Faktor hormonal juga mempengaruhi perubahan berat badan, hal ini sesuai dengan teori Hartanto (2004) mengatakan bahwa faktor hormonal mempengaruhi perubahan pola makan yang menyebabkan terjadinya perubahan berat badan. Faktor penyakit juga mempengaruhi terjadinya perubahan berat badan misalnya pada penyakit gastritis atau penyakit infeksi lainnya yang mempengaruhi perubahan pola makan ibu sehingga asupan nutrisi berkurang dan terjadi penurunan berat badan.

3. Hubungan Tingkat Pengetahuan Tentang Emesis Gravidarum Dengan Perubahan Berat Badan Ibu Hamil Trimester 1

Berdasarkan uji hipotesa didapat Ha diterima yang artinya terdapat hubungan yang kuat dan signifikan antara tingkat pengetahuan tentang emesis gravidarum dengan perubahan berat badan ibu hamil trimester 1 . Berdasarkan hasil penelitian di Puskesmas Baturiti I menunjukan bahwa dari 34 responden terdapat ibu hamil yang mengalami emesis gravidarum memiliki pengetahuan yang baik tentang emesis gravidarum dan mengalami kenaikan berat badan yaitu sebanyak 4 orang $(11,76 \%)$, ibu hamil yang mengalami emesis gravidarum yang berpengetahuan cukup, tidak mengalami perubahan berat badan yaitu sebanyak 5 orang $(14,70 \%)$ dan ibu hamil yang mengalami emesis grvaidarum yang memiliki pengetahuan kurang dan mengalami penurunan berat badan yaitu sebanyak 15 orang $(44,11 \%)$. Dari hasil penelitian yang dilakukan di Puskesmas Baturiti I menunjukan bahwa tingkat pengetahuan tentang emesis gravidarum dapat dinyatakan berhubungan dengan 
perubahan berat badan, artinya ibu hamil yang mengalami penurunan berat badan disebabkan oleh tingkat pengetahuan ibu yang kurang tentang emesis gravidarum.

Pengetahuan akan merangsang ibu untuk berpikir dan berusaha untuk mencari penyelesaian tentang emesis gravidarum menjadi lebih baik sehingga berat badan ibu tidak turun atau dapat dipertahankan. Pengetahuan tentang emesis gravidarum sangat berpengaruh terhadap sikap dalam mengatasi emesis gravidarum sehingga perubahan berat badan dapat berubah secara signifikan.

Pengetahuan ibu yang baik dalam mengatasi emesis gravidarum yang dialaminya dengan berbagai cara diantaranya mengkonsumsi makanan yang dapat mengurangi rasa mual seperti roti-roti kering, menghindari makan makanan berminyak,segera memeriksakan kondisi ibu dan kehamilannya apabila keluhan ibu bertambah parah, dan rutin melakukan ANC akan mengalami kenaikan berat badan. Sebaliknya ibu yang kurang pengetahuannya tentang emesis gravidarum yang dialaminya akan cenderung menghadapi masalah sehingga meyebabkan terjadinya penurunan berat badan.

\section{SIMPULAN}

Berdasarkan hasil penelitian yang telah dilakukan mengenai hubungan tingkat pengetahuan ibu hamil tentang emesis gravidarum dengan perubahan berat badan ibu hamil trimester I di Puskesmas Baturiti I bahwa didapat hasil adanya hubungan yang kuat dan signifikan antara tingkat pengetahuan tentang emesis gravidarum dengan perubahan berat badan ibu hamil trimester I di Puskesmas Baturiti I yang dapat disimpulkan sebagai berikut :

a. Rata-rata ibu hamil trimester 1 yang mengalami emesis gravidarum memiliki pengetahuan tentang emesis gravidarum dalam kategori tingkat pengetahuan kurang. b. Sebagian besar perubahan berat badan yang dialami oleh ibu hamil trimester 1 yang mengalami emesis gravidarum dalam kategori berat badan turun.

c. Ada hubungan yang kuat dan signifikan antara tingkat pengetahuan tentang emesis gravidarum dengan perubahan berat badan ibu hamil trimester I di Puskesmas Baturiti I.

\section{REFERENSI}

Prawirohardjo, Sarwono. (2007). Ilmu Kebidanan. Jakarta : Yayasan Bina Pustaka Sarwono Prawirohardjo

Manuaba, IBG. (2006). Ilmu Kebidanan, Penyakit Kandungan dan Keluarga Berencana Untuk Pendidikan Bidan. Jakarta:EGC

Mochtar, Rustam. (2005). Sinopsis Obstetri edisi I.Jakarta:EGC

Notoatmodjo. (2010).Metodelogi Penelitian Kesehatan. Edisi Revisi, PT Rineka Cipta, Jakarta

Lily, Yulaikhah. (2006). Seri Asuhan Kebidanan Kehamilan. Jakarta : EGC

Nursalam. (2008). Konsep dan Penerapan Metodelogi Penelitian Ilmu Keperawatan.Jakarta: Salemba Medika

Kusmiyati Yuni, Heni Puji Wahyuningsih, Sujiyatini. (2009). Perawatan Ibu Hamil. Yogyakarta : Fitramaya

Achadiat, Chrisdiono M. (2004). Prosedur Tetap Obstetri dan Ginekologi. Jakarta : EGC

Hadi, Sutrisno. (2004). Metodologi Research Jilid 1.Yogyakarta:Andi 
Arikunto, Suharsimi. (2010). Prosedur Penelitian Suatu Pendekatan Praktik Edisi Revisi. Rineka Cipta, Jakarta.

Hadi, Sutrisno. (2004). Metodologi Statistik Jilid 2 .Yogyakarta:Andi

Maydav.

(2011). http://maydav.wordpress.com/2 011/08/13/penyebab-turunnyaberat-badan-secara-drastis/ diakses tgl 7 April 2013, jam $18.30 \mathrm{wib}$

Sanjaya, Ade. (2011). http://aadesanjaya.blogspot.com /2011/09/pengertian-beratbadan.html, diakses tgl 20 April 2013, jam $15.00 \mathrm{wib}$

Sekartaji, Arum. (2011). http://arumsekartaji.wordpress.c om/2011/03/30/jaga-makanansaat-hamil/ diakses tgl 21 April 2013, jam 15.00 wib 